\title{
Thermostability and free radical scavenging activity of Annona muricata (L.) leaf extract in antiaging cream
}

\author{
Alvin Aldo ${ }^{1}$, Gabriela Eugresya ${ }^{2}$, Mediana Hadiwidjaja ${ }^{2}$, Christina Avanti ${ }^{* 1}$ \\ ${ }^{I}$ Department of Pharmaceutics, Faculty of Pharmacy, The University of Surabaya (UBAYA) \\ Jl. Raya Kalirungkut, Surabaya-60293, Jawa Timur, Indonesia \\ ${ }^{2}$ Infinisia Sumber Semesta, Jl. Daan Mogot KM 17, Kompleks Imperial Business Center \\ Block F6-7, Kalideres, Jakarta Barat, Jakarta-11840, Indonesia
}

Submitted: 30-06-2018

Reviewed: 13-08-2018

Accepted: 27-03-2019

\begin{abstract}
Annona muricata is an Indonesian medicinal plant commonly used as an anticancer agent. The finding of its strong antioxidant activity leads to the development of cosmetic products, particularly as antiaging cream. Formulation may influence thermostability and free radical scavenging activity of A.muricata leaf extract. The purpose of this study was to investigate the thermostability and free radical scavenging activity of A.muricata leaf extract incorporated in Gattefosse Skin Cashmere cream. Accelerated stability study utilizing climatic chamber at a temperature of $40^{\circ} \mathrm{C} \pm 2^{\circ} \mathrm{C}$ and relative humidity of $75 \% \pm 5 \%$ for 20 days of storage was used to evaluate thermostability. 1,1diphenyl-2-picrylhydrazil (DPPH) using spectrophotometer was used for free radical scavenging activity test. The result from physical properties including appearance of antiaging cream, $\mathrm{pH}$, viscosity and rheological properties of each formula showed that all of the formulas were stable at a temperature of $40^{\circ} \mathrm{C} \pm 2^{\circ} \mathrm{C}$ and relative humidity of $75 \% \pm 5 \%$ for 20 days. Free radical scavenging activity using DPPH showed high antioxidant activities from the A.muricata leaf extract in the Gattefosse Skin Cashmere cream. We concluded that A. muricata leaf extract could be developed into natural antiaging cosmetic product.
\end{abstract}

Keywords: A.muricata, antiaging cream, thermostability, free radical scavenging activity

\footnotetext{
*Corresponding author:

Christina Avanti

Department of Pharmaceutics, Faculty of Pharmacy

The University of Surabaya, Surabaya

Jl. Raya Kalirungkut, Surabaya-60293

Email:c_avanti@staff.ubaya.ac.id
} 


\section{INTRODUCTION}

Annona muricata or also well known as graviola, soursop, paw-paw, guanabana and sirsak is one from 2300 different species of Annonaceae family. This specific species is mostly grown in tropical-subtropical areas, for example South and North America, India, Malaysia, Nigeria, also in Indonesia. Currently, A. muricata is widely used in food and beverage industry, as well as in herbal medicine mainly as potent anticancer agent (Moghadamtousi et al., 2015). Previous research proved that Annonaceous acetogenin from A. muricata leaf extract has been beneficial on repairing pancreatic tissues, which subjected to Streptozotocin-induced oxidative stress and succeeded to diminish pancreatic oxidative damage produced by Streptozotocin (Adewole and Ojewole 2009). Annonaceous acetogenin in A. muricata leaf contains high antioxidant activity that can potentially be developed into a promising natural antiaging cosmetic.

Antiaging cosmetic products can be developed through incorporating A. muricata into oil in water emulsion based formulation. There are several cream bases that have been widely used in the market as a vehicle for antiaging from natural extracts. One of the most commonly used creams recently is Gattefose Skin Cashmere. Formulation may affect the efficacy of the extract on antioxidant activity as well as its thermal stability.

Accelerated stability study is one of the most common and widely used studies for thermostability. The test is similar to a real-time stability test using climatic chamber that is performed to provide the shelf life of product under appropriate storage condition, but in a relatively short time. This test is usually performed less than 3 months to forecast the 1-year shelf life of the product. Furthermore, the condition for product storage in accelerated stability test is usually performed at temperature of $37^{\circ} \mathrm{C}, 40^{\circ} \mathrm{C}$ and $45^{\circ} \mathrm{C}$ with relative humidity of $75 \%$ and might different each country depending on the climate zone. The assessment criteria for this test are the physical conditions of the product including its appearance, odor and color, $\mathrm{pH}$, viscosity and phase separation (Association 2004; Bajaj et al., 2012).

The determination of free radical scavenging of A. muricata leaf extract was done by using 1,1diphenyl-2-picrylhydrazil (DPPH) with spectrophotometer. This study is very important as a preliminary study to know the strength of the free radical scavenging activity from the A. muricata leaf alone, before formulated into an antiaging cream. We concluded that the A. muricata leaf extract has a very strong potential as an antioxidant with highest antioxidant activity observed on ethanolic extract of the A. muricata leaf. Furthermore, the thermostability of each formula could be observed from accelerated stability study in which each formula was being evaluated after 20 days in a controlled high temperature storage for their physio-chemical properties such as appearance, odor, color, $\mathrm{pH}$, viscosity, rheological properties and antioxidant activity.

The purpose of this study was to investigate the thermostability of an antiaging cream containing A. muricata leaf extract and to know the strength of the free radical scavenging of the A. muricata leaf extract alone. Additionally, we evaluated how far A. muricata leaf extract could enhance the antioxidant activity from the Gattefosse skin cashmere cream and also kept the product remain stable in high temperature.

\section{MATERIALS AND METHOD Materials}

A. muricata dried leaf was purchased from Materia Medica (Batu, Malang, Indonesia), DPPH and glycerin were purchased from Sigma-Aldrich (St. Louis, MO, USA).The antiaging skin creams were prepared based on the ingredients listed on Table I. There were 3 formulas using a similar cream base, Formula F1 was cream based without active ingredients, Formula F2 contained 5\% of water extract from A. muricata leaf and Formula F3 contained 5\% of ethanolic extract from A. muricata leaf as an active ingredient. 
Table I. Ingredients, suppliers and composition (\% weight) of the gattefosse skin cashmere cream

\begin{tabular}{|c|c|c|}
\hline Components (INCI) & Suppliers & $\% w / w$ \\
\hline $\begin{array}{c}\text { Cetyl Alcohol, Glyceryl Stearate, } \\
\text { PEG-75 Stearate, Ceteth-20 and } \\
\text { Steareth-20 }\end{array}$ & 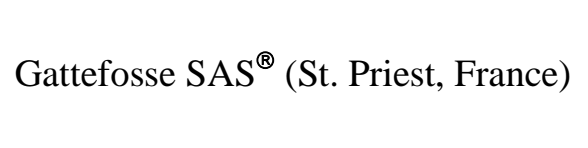 & 3.00 \\
\hline $\begin{array}{l}\text { Cyclopentasiloxane and } \\
\text { Cyclohexasiloxane }\end{array}$ & Dow Corning $^{\circledR}$ (Michigan, US) & 4.00 \\
\hline Caprylic/Capric Triglyceride & Gattefosse $\mathrm{SAS}^{\circledR}$ (St. Priest, France) & 3.00 \\
\hline Tocopheryl Acetate & $\begin{array}{c}\text { Zhejiang Medicine }{ }^{\circledR} \text { (Xinchang, } \\
\text { China) }\end{array}$ & 1.00 \\
\hline Jojoba Oil & Dessert King $^{\circledR}$ (Mexico, US) & 1.50 \\
\hline Propylene Glycol Dipelargonate & Gattefosse $S A S^{\circledR}$ (St. Priest, France) & 4.00 \\
\hline Phenoxyethanol & Sigma-Aldrich $^{\circledR}$ (St. Louis, US) & 0.70 \\
\hline Glycerin & Sigma-Aldrich $^{\circledR}$ (St. Louis, US) & 4.00 \\
\hline Butylene Glycol & Sigma-Aldrich $^{\circledR}$ (St. Louis, US) & 2.00 \\
\hline Carbopol ETD 2050 & Lubrizol $^{\circledR}$ (Ohio, US) & 0.15 \\
\hline Xanthan Gum & Rhodia $^{\circledR}$ (Mumbai, India) & 0.30 \\
\hline Sodium Hydroxide & Sigma-Aldrich $^{\circledR}$ (St. Louis, US) & 0.30 \\
\hline Perfume Soyeux & $\begin{array}{c}\text { Expressions Parfumees }{ }^{\circledR} \text { (Grasse, } \\
\text { France) }\end{array}$ & 0.20 \\
\hline Water & - & ad 100 \\
\hline
\end{tabular}

INCI= International Nomenclature of Cosmetic Ingredients.

\section{Preparation of skin cream}

Formula F1 consist of base skin cream formula which prepared by dispersing Carbopol ETD 2050 and xanthan gum into water under stirring. Glycerin butylene glycol was then added into water and heated to $75^{\circ} \mathrm{C}$ (water phase). The oil phase consist of Cetyl Alcohol, Glyceryl Stearate, PEG-75 Stearate, Ceteth-20 and Steareth-20, Cyclopentasiloxane and Cyclohexasiloxane, Caprylic/Capric Triglyceride, Tocopheryl Acetate, Jojoba Oil, Propylene Glycol Dipelargonate and phenoxy ethanol were heated at a temperature of $75^{\circ} \mathrm{C}$. Oil phase and water phase were mixed by $5,000 \mathrm{rpm}$ speed for 3 minutes at $75^{\circ} \mathrm{C}$. Sodium hydroxide $\left(10 \%\right.$ sol) was added and cooled under normal stirring until $35^{\circ} \mathrm{C}$ temperature was achieved, perfume was then added, and cooled completely. In formula F2, the water leaf extract was first incorporated into water phase before heating, then skin cream was prepared as formula F1. While formula F3 the ethanolic leaf extract was first incorporated into oil phase before heating. And manufacturing process was following Formula F1 preparation.

\section{Accelerated stability study}

To obtain thermostability data of the skin cream at all formulas, an accelerated stability study was conducted for 20 days by using climatic chamber with a temperature of $40^{\circ} \mathrm{C} \pm 2^{\circ} \mathrm{C}$ and relative humidity of $75 \% \pm 5 \%$. Parameters that have been measured were organoleptic, $\mathrm{pH}$, rheological properties, and antioxidant activity. Data were taken at day 0, 5, 10,15 and 20. 


\section{Organoleptic}

The characteristics of the skin cream were determined by sensory for its appearance or homogeneity, odor and color. The homogeneity of formulations were tested by visual appearance and by touch.

pH

Surface $\mathrm{pH}$ of each formula was measured using $\mathrm{pH}$ meter (Schoot lab 850, USA) by bringing the electrode into contact with cream surface and allowing it to equilibrate for 1 minute.

\section{Rheological properties}

Rheological properties were determined by using Brookfield DV-I type cone and plate viscometer (Ametek Brookfield, Middleboro, USA). Viscosities of skin cream in various rate of shear was measured by applying $2.0 \mathrm{~g}$ of sample on the stationary plate and raised into the position under the cone which was then rotated by speed motor on the rate of shear from 0.5-10 rpm. The rheological characteristic of the skin cream was determined by plotting viscosity as a function of rate of shear in the \%torque at a range of 10\%-100\% (Mishra et al., 2014; Inoue et al., 2014).

\section{DPPH free radical scavenging test}

The DPPH free radical scavenging test was performed on skin creams Formula F1, F2 and F3 before and after storage in climatic chamber for 5, 10, 15 and 20 days. Free radical scavenging activity was determined by dissolving $1.0 \mathrm{~g}$ of the skin cream into $50.0 \mathrm{~mL}$ of $80 \%$ ethanol (sample solution). $1.0 \mathrm{~mL}$ of sample solution was mixed by $3.0 \mathrm{ml}$ of $50.0 \mathrm{ppm}$ DPPH solution and $1.0 \mathrm{~mL}$ of ethanol $80 \%$ in the glass tube, then incubated for 16 minutes under room temperature and low light condition. Absorbance of the solution was obtained from spectrophotometer (Shimadzu Corp. ${ }^{\circledR} \mathrm{UV}$ 1800, Kyoto, Kyoto Prefecture, Japan) at the wavelength of $520 \mathrm{~nm}$ using visible light detector. Antioxidant activity was calculated from Absorbance using equation as follows (Ratih et al., 2015):

$$
\text { \%Inhibition }=\frac{(\text { AbsDPPH-Abs sample) }}{\text { Abs DPPH }} \times 100 \%
$$

\section{Data Analysis}

Data from $\mathrm{pH}$, viscosity, and antioxidant activity were analyzed using one-way ANOVA of IBM SPSS ${ }^{\circledR}$ Version 23.0 software (Armonk, New York, USA).

\section{RESULTS AND DISCUSSION}

Organoleptic result from each formula listed on the Table II shows that there was no significant change in the appearance and homogeneity of the skin cream before and after 20 days of accelerated stability study at a temperature of $40^{\circ} \mathrm{C} \pm 2{ }^{\circ} \mathrm{C}$ and $75 \% \pm 5 \%$ relative humidity. Figure 1 shows that antiaging creams Formula F2 and Formula F3 containing A.muricata leaf extract differed in color. Etanolic extract A.muricata skin cream showed darker color compared to Formula 2. While Formula F2, water extract A.muricata skin cream showed light brown color since the manufacturing process and Formula F1, cream based formula without any active ingredients showed white color. Diluted perfume that has been added to the formula in order to mask the strong odor from A.muricata leaf extract was creating pleasant odor and remained the same after storage. The physical appearances of all formulas were acceptable with the specific color and odor since an antiaging skin cream is intended to be used daily. 
Table II. Organoleptic result of A.muricata leaf extract cream before and after accelerated stability test

\begin{tabular}{|c|c|c|c|c|}
\hline \multirow{2}{*}{ Days } & \multirow{2}{*}{ Formula } & \multicolumn{3}{|c|}{ Parameters } \\
\hline & & Homogeneity & Appearance & Odor \\
\hline 0 & $\begin{array}{l}\text { F1 } \\
\text { F2 } \\
\text { F3 }\end{array}$ & Good & $\begin{array}{l}\text { No Change in } \\
\text { Color }\end{array}$ & No Change \\
\hline 5 & $\begin{array}{l}\text { F1 } \\
\text { F2 } \\
\text { F3 }\end{array}$ & Good & $\begin{array}{l}\text { No Change in } \\
\text { Color }\end{array}$ & No Change \\
\hline 10 & $\begin{array}{l}\text { F1 } \\
\text { F2 } \\
\text { F3 }\end{array}$ & Good & $\begin{array}{c}\text { No Change in } \\
\text { Color }\end{array}$ & No Change \\
\hline 15 & $\begin{array}{l}\text { F1 } \\
\text { F2 } \\
\text { F3 }\end{array}$ & Good & $\begin{array}{c}\text { No Change in } \\
\text { Color }\end{array}$ & No Change \\
\hline 20 & $\begin{array}{l}\text { F1 } \\
\text { F2 } \\
\text { F3 }\end{array}$ & Good & $\begin{array}{l}\text { No Change in } \\
\text { Color }\end{array}$ & No Change \\
\hline
\end{tabular}

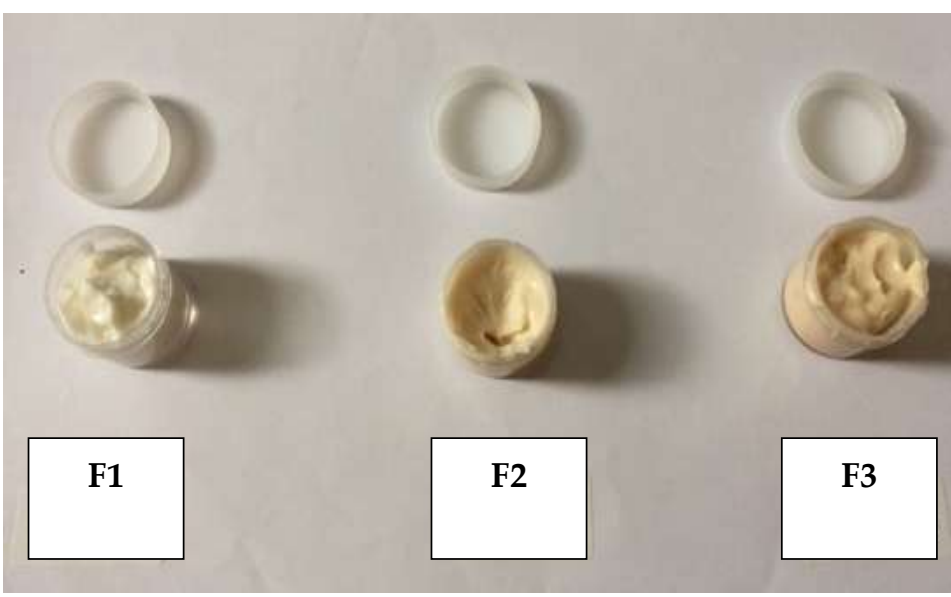

Figure 1. Skin Cream Appearance

The antiaging creams are used mainly as daily creams to prevent premature aging on the skin. For this purpose, all of the formulated skin creams should be on the range of human skin surface, which is 4-6 to prevent irritation (Mishra et al., 2014; Ali and Yosipovitch 2013). pH results of each formula in Figure 2 showed that there were no significant differences on $\mathrm{pH}$ during storage. It means that all formulas had good $\mathrm{pH}$ stability. However there were significant differences in $\mathrm{pH}$ among all three formulas due to the addition of A.muricata leaf extract. $\mathrm{pH}$ on Formula F2 and F3 showed a significant difference compared to $\mathrm{pH}$ on Formula $\mathrm{F} 1$ because of the addition of A.muricata leaf extract as active ingredient. Surface pH of Formula F2 was higher than Formula F3 due to the difference of extract vehicle, whereas water on Formula F2 and ethanol on Formula F3. 


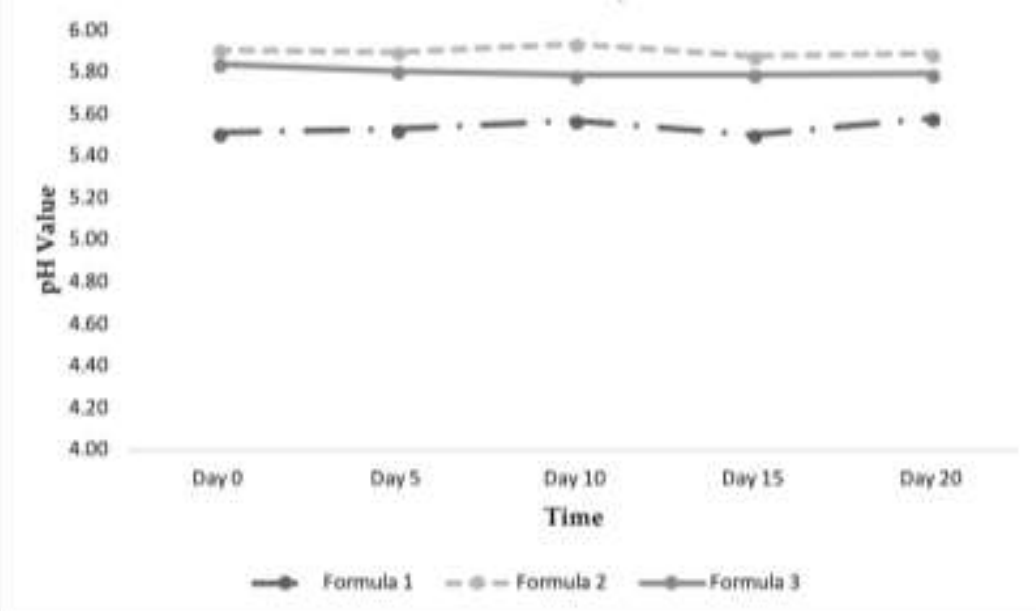

Figure 2. Surface $\mathrm{pH}$ of A.muricata leaf extract cream before and after accelerated stability test

Rheological properties are the most important aspects in the formulation of skin creams. It plays important role in gaining information on whether the skin cream can easily spread on the skin and has a good consistency. Skin creams have viscosity ranging between $13.670 \mathrm{cps}$ to $16.760 \mathrm{cps}$ on $0.5 \mathrm{rpm}$ using C41 cone spindle. The viscosity result of each formula before and after the accelerated stability test was conducted is listed on Table III. All skin creams formulas provided shear thinning characteristic, which can be seen from the decreasing viscosity by increasing the rate of shear.

There were no significant ( $p>0,05)$ differences on F1 compare to F2 (group a) and on F2 compare to F3 (group b) based on viscosity, but there were significant $(\mathrm{p}<0,05)$ differences on F1 compare to F3. The skin cream with ethanolic extract of A.muricata leaf, Formula F3, was the most viscous cream among others. It happened because ethanolic extract was added before heating process in cream manufacturing, leading to an evaporation of ethanol in the process and making the oil phase of the cream become denser and more viscous. Formula F2 has higher viscosity compared to bases, it related to the addition of 5\% water extract A.muricata leaf as active ingredients. Furthermore, the ethanolic extract was more volatile than the water extract and both extracts were incorporated into the formula before the heating process. This made Formula F3 had loss extract vehicle in the process more than that of Formula F2, and made Formula F3 become denser than Formula F2. This explains why Formula F3 was more viscous than Formula F2.

Table III. Viscosity result of A.muricata leaf extract cream on 0.5 RPM before and after accelerated stability test

\begin{tabular}{|c|c|c|c|c|c|c|c|}
\hline Formula & $\begin{array}{c}\text { Day 0 } \\
\text { (cps) }\end{array}$ & $\begin{array}{l}\text { Day } 5 \\
\text { (cps) }\end{array}$ & $\begin{array}{c}\text { Day } 10 \\
\text { (cps) }\end{array}$ & $\begin{array}{c}\text { Day } 15 \\
\text { (cps) }\end{array}$ & $\begin{array}{c}\text { Day 20 } \\
\text { (cps) }\end{array}$ & $\begin{array}{c}\text { Statistical } \\
\text { Analysis }\end{array}$ & Sigg. \\
\hline 1 & 14.560 & 14.430 & 13.950 & 13.750 & 13.670 & 14.072 & \multirow{3}{*}{$\begin{array}{l}0,181 \\
0,519\end{array}$} \\
\hline 2 & 15.950 & 15.450 & 14.680 & 14.440 & 14.330 & 14.970 & \\
\hline 3 & 16.760 & 16.160 & 15.220 & 14.880 & 14.490 & 15.502 & \\
\hline
\end{tabular}

Statistical analysis result showed no significance difference between formula F1 and F2 $(0,181)$ and F2 and F3 $(0,519) \mathrm{P}(>0,005)$ 
For rheological properties of Formula F1, Formula F2 and Formula F3 before and after the accelerated stability test was performed are illustrated on Figure 3, Figure 4 and Figure 5. All figures showed significantly decreased of viscosity on each formula during storage for 20 days. However all formula maintained similar rheological properties, which means all skin cream formula provided shear thinning systems or pseudoplastic behavior with time dependent properties and was considered as physically stable.

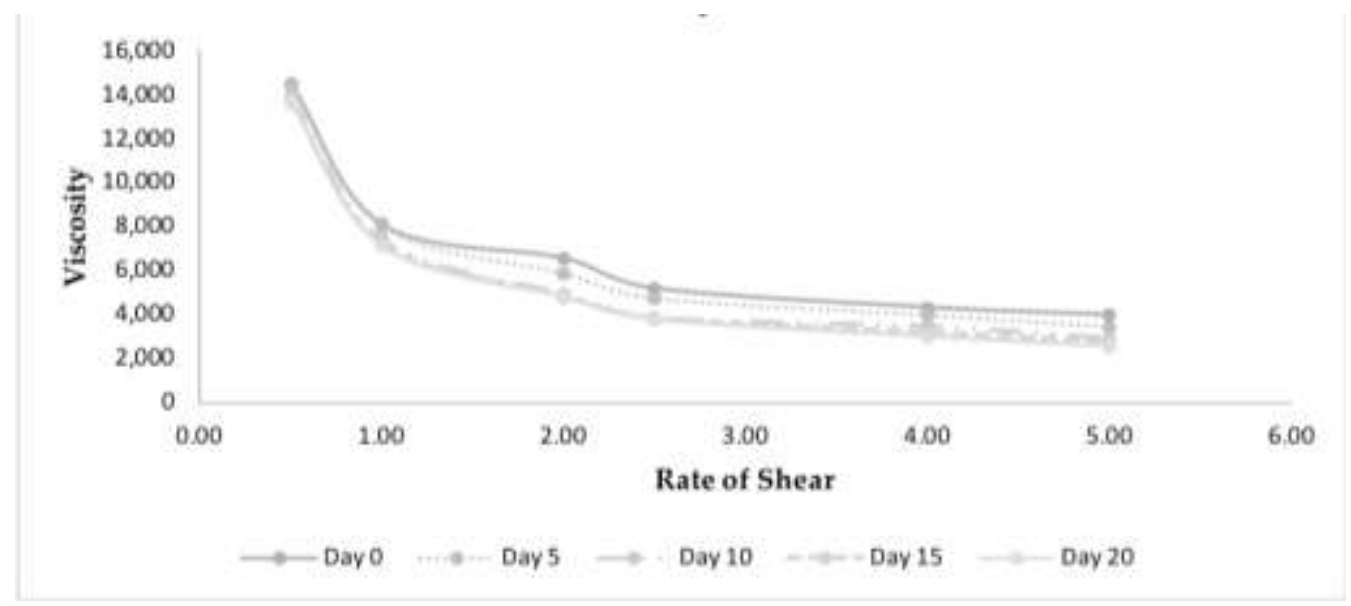

Figure 3. Rheological properties of A.muricata leaf extract cream (Formula 1) before and after accelerated stability test

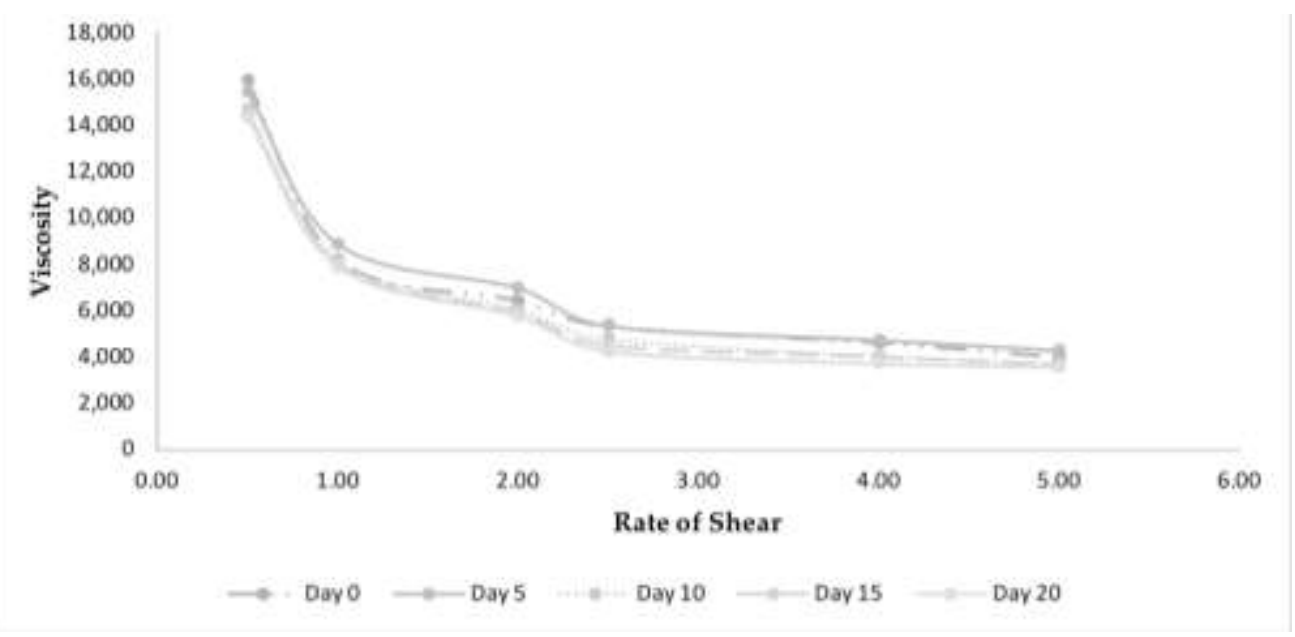

Figure 4. Rheological Properties of A.muricata leaf extract cream (Formula 2) before and after accelerated stability test 


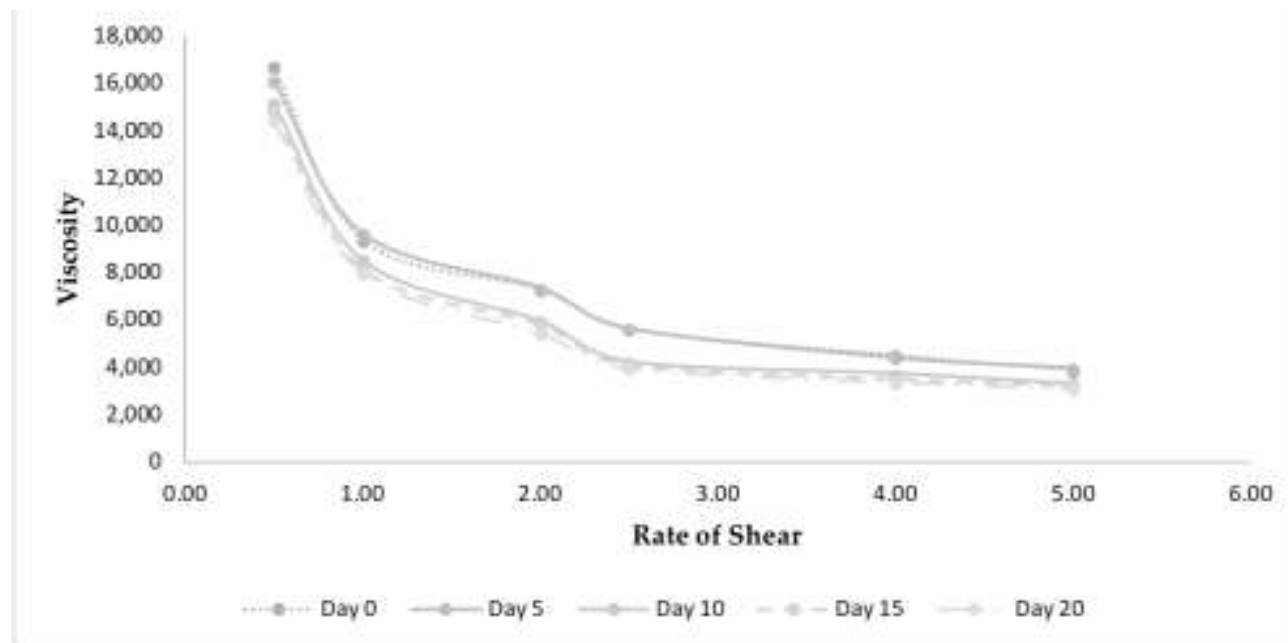

Figure 5. Rheological properties of A.muricata leaf extract cream (Formula 3) before and after accelerated stability test

Based on Figure 3, Figure 4 and Figure 5, it can be concluded that all formulas showed a nonnewtonian pseudoplastic behavior since viscosity was decreased by increasing the rate of shear and the rheological characteristic of all formulas remained the same after the accelerated stability study, but the viscosity of all formulas decreased by time, which means all formulas had time dependent properties. According to Kwak et al. (2015), non-newtonian pseudoplastic (shear thinning) flow behavior is considered desirable for topical preparations since it improves the spreading of the product on the skin and it also indicates that the product has good spreadability on the skin (Kwak et al., 2015; European Commission 2016). Statistic result indicated that all formulas demonstrated no significant difference in viscosity, and exhibit the same rheological properties as their initial viscosity. Hence, all of the formulas provided good stability and good spreading on the skin.

Moreover, antioxidant activities from all skin creams formulas were also measured. DPPH method utilizing spectrophotometer before and after accelerated stability test was performed. Results from the antioxidant activity are represented as \%inhibition and can be seen on Table IV.

Table IV. Antioxidant activity of A.muricata Leaf extract cream before and after accelerated stability test

\begin{tabular}{ccccccc}
\hline Formula & $\begin{array}{c}\text { Day 0 } \\
(\boldsymbol{\%})\end{array}$ & $\begin{array}{c}\text { Day 5 } \\
(\mathbf{\%})\end{array}$ & $\begin{array}{c}\text { Day 10 } \\
(\mathbf{\%})\end{array}$ & $\begin{array}{c}\text { Day 15 } \\
(\mathbf{\%})\end{array}$ & $\begin{array}{c}\text { Day 20 } \\
(\boldsymbol{\%})\end{array}$ & $\begin{array}{c}\text { Statistical } \\
\text { Analysis }\end{array}$ \\
\hline 1 & 37,37 & 37,54 & 37,79 & 37,09 & 37,96 & 37,55 \\
2 & 54,89 & 54,78 & 55,29 & 54,26 & 54,89 & 54,82 \\
3 & 62,92 & 62,32 & 62,94 & 61,62 & 63,07 & 62,57 \\
\hline
\end{tabular}

Statistical analysis result showed Significance difference between each formula $\mathrm{P}(<0,005)$

Formulated skin creams containing A.muricata leaf extract showed good antioxidant activity and good stability during 20 days of storage. Based on the test result (Table IV), the skin cream formula containing A.muricata leaf extract had a strong potential to be developed as antiaging product. The skin cream base or Formula F1 already provided antioxidant activity that comes from ingredients 
such as jojoba oil and alpha tocopherol, but the antioxidant activity result from Formula F1 was not as good as the other two formulas containing the A.muricata leaf extract, which were Formula F2 and Formula F3. The formulated skin cream containing ethanolic extract of A.muricata leaf showed better results in antioxidant activity than the water based extract. From statistic result, antioxidant activities of all skin creams formulas were significantly different due to the addition of an active ingredient, which was A.muricata leaf extract. Furthermore, the water extract was more compatible to the formula since the skin cream formula consists mostly of water and is also more acceptable to the market.

\section{CONCLUSION}

We concluded that the A.muricata leaf extract is a promising natural ingredient that might be developed into natural-based antiaging cosmetic. A.muricata leaf extract showed thermally stable based on the physio-chemical properties result from the accelerated stability study, and DPPH result demonstrated that the cream containing A.muricata leaf extract had higher antioxidant value compared to the cream without A.muricata leaf extract.

\section{ACKNOWLEDGEMENTS}

Author would like to thank PT. Infinisia Sumber Semesta for providing cream based materials and Materia Medica for providing A.muricata leaf extract. Authors also received funds for covering the costs to publish in open access from University of Surabaya.

\section{REFERENCES}

Adewole, S.O. \& Ojewole, J.A.O., 2009. Protective effects of Annona muricata Linn. (Annonaceae) leaf aqueous extract on serum lipid profiles and oxidative stress in hepatocytes of streptozotocin-treated diabetic rats. African Journal of Traditional, Complementary and Alternative Medicines, 6(1): 30-41.

Ali, S.M. \& Yosipovitch, G., 2013. Skin pH: From basic science to basic skin care. Acta DermatoVenereologica, 93(3): 261-267.

Association, C.T. and F.A. and T.E.C.T. and P., 2004. Guidelines on Stability Testing of Cosmetic Products. Cosmetic Toiletry and Fragrance Association and The European Cosmetic Toiletry and Perfumery Association, (March): 1-8.

Bajaj, S., Sakhuja N. \& Singla D., 2012. Stability Testing of Pharmaceutical Products. Journal of Applied Pharmaceutical Science, 2: 129-138.

European Commission, 2016. the Sccs Notes of Guidance for the Testing of Cosmetic Ingredients. Sccs: $1564,151$.

Inoue, Y., Suzuki K., Maeda R., Shimura A., Murata I. \& Kanamoto I., 2014. Evaluation of formulation properties and skin penetration in the same additive-containing formulation. Results in Pharma Sciences, 4: 42-49.

Kwak, M.S., Ahn, H.J. \& Song, K.W., 2015. Rheological investigation of body cream and body lotion in actual application conditions. Korea Australia Rheology Journal, 27(3): 241-251.

Mishra, A.P., Saklani S.,Millela L. \& Tiwari P., 2014. Formulation and evaluation of herbal antioxidant face cream of Nardostachys jatamansi collected from Indian Himalayan region. Asian Pacific Journal of Tropical Biomedicine, 4(Suppl 2): 679-682.

Moghadamtousi, S.Z., Fadaeinasab M., Nikzad S. \& Mohan G., 2015. Annona muricata (Annonaceae): A Review of Its Traditional Uses, Isolated Acetogenins and Biological Activities. Int. J. Mol. Sci., 16: 15625-15658. 
Ratih, Kohar I., Qalbye A.M., Arbi H. \& Allaf K., 2015. The Antioxidant Activities of the Extracts of Red Fruit (Pandanus conoideus Lam.) Pre-dried by Détente Instantanée Contrôlée (DIC). Journal of Medical Investigation, 52(Il): 65-75. 